\title{
ANALISIS SIKAP DAN KEPUASAN KONSUMEN TERHADAP ATRIBUT PRODUK KARKAS AYAM PEDAGING SEGAR DI PASAR TRADISIONAL KOTA SAMARINDA
}

\section{ANALYSIS OF ATTITUDE AND CUSTOMER SATISFACTION ON ATTRIBUTES OF FRESH CHICKEN CARCASS IN TRADITIONAL MARKET CITY SAMARINDA}

\author{
Arif Ismanto, Try Julianda, Mursidah \\ Jurusan Peternakan, Fakultas Pertanian, Universitas Mulawarman, Samarinda
}

ABSTRACT

Article history

Accepted: June 10, 2018 ;

Approved: July 1, 2018

* Corresponding author:

E-mail:

arifismanto9@gmail.com,

tryjulianda@gmail.com, mursidah.spmm@gmail.com
This research aims to know the attitude of consumers, the level of satisfaction, and what product attributes that are considered consumers before buying the broiler carcass in traditional market of Samarinda City. The data retrieval research conducted during November 2016. The basic method of research is using descriptive method, and it's implementation with the technique level. The location of the study was chosen intentionally in Samarinda City by taking 3 traditional markets as a sample. The determination of the number of samples is done proportionally and the technique of determining the sampling method by chance (Accidental sampling) with the number of samples of 50 respondents. The type of data used is primary data and secondary data with data collection techniques by observation, interview, and recording. The analysis used is Fishbein Multi Attribute attitude analysis and to analyze satisfaction using Customers Satisfaction Index. The result of the research based on analysis of Fishbein Multiatribut known to consumer attribute value toward color attribute 16.80, weight (16.48), aroma (15.76), skin hygiene (14.57) and price (13.11). Based on Costumer Satification Index the level of customer satisfaction on broiler carcass is $77.11 \%$. Result of research based on analysis of Fishbein Multi Attribute known consumer attitude toward carcass is "positive" which means consumers are well-receptive to broiler carcass in traditional markets with most attributes considered in the purchase decision of chicken carcasses in traditional markets of Samarinda City is the color of broiler carcasses. The order of attributes from the most considered to the least considered is color, carcass weight, aroma, skin hygiene and broiler carcass price. Based on Customer Satisfaction Index of consumer satisfaction level against broiler carcass is $77.11 \%$ who are satisfied category.

Key words: Carcass Broiler; Fishbein Multi Attribute; customer satisfaction index; traditional market; Samarinda 


\section{PENDAHULUAN}

Salah satu tujuan dari budidaya ternak adalah untuk menghasilkan pangan sumber gizi yang berasal dari daging, telur dan susu bagi pemenuhan kebutuhan manusia. Pemenuhan pangan sumber tersebut biasanya diperoleh masyarakat dengan membeli di pasar tradisional ataupun pasar modern. Tambunan (2009), menyatakan bahwa $70 \%$ konsumsi daging dipenuhi dari pasar tradisional, dan hanya 30\% di supermarket atau pasar modern. Pasar tradisional menampung banyak penjual yang mewakili golongan pedagang menengah ke bawah dan mulai beroperasi dari dini hari sampai dengan siang atau sore hari.

Kota Samarinda memiliki jumlah penduduk tertinggi diantara kabupaten/kotamadya lain di Kalimantan Timur yaitu sebanyak 830.676 jiwa pada tahun 2014 (BPS, 2015). Banyaknya jumlah penduduk, peningkatan pendapatan, pengetahuan serta kesadaran masyarakat terhadap nilai gizi dari pangan turut andil dalam peningkatan konsumsi daging ayam. Pratama (2013), mengatakan bahwa terdapat faktor yang mempengaruhi jumlah pembelian karkas ayam pedaging yaitu pendapatan keluarga, jumlah anggota keluarga, harga, dan kualitas karkas ayam pedaging.

Berdasarkan data dari Dinas Pengelola Pasar Kota Samarinda (2016), terdapat sekitar 3-70 pedagang karkas ayam pedaging segar di setiap pasar tradisional, hal tersebut mengakibatkan persaingan pemasaran antar pedagang semakin ketat karena banyaknya pedagang ayam pedaging mempengaruhi peluang setiap pedagang untuk mendapatkan lebih banyak konsumen akan menjadi semakin sedikit. Produsen dan pemasar, perlu mengetahui selera konsumen dalam menentukan pilihan suka atau tidak suka seorang konsumen terhadap suatu atribut produk agar dapat mempengaruhi keputusan konsumen, mengingat konsumen selalu memperhatikan berbagai macam atribut yang melekat pada produk sebagai bahan pertimbangan sebelum pengambilan keputusan pembelian (Sumarwan, 2004).

Persaingan dalam pemasaran yang semakin ketat mendorong para produsen dan pemasar untuk memilih strategi pemasaran yang tepat dan efisien dalam memasarkan produk yang dihasilkan. Pemasaran bukanlah semata-mata membuat penjualan, namun pemasar harus bisa menentukan kebutuhan konsumen yang dapat dipenuhi dengan menguntungkan serta bagaimana melayani konsumen secara lebih efektif dan efisien agar dapat diciptakan suatu kepuasan konsumen. Mencapai tingkat kepuasan pelanggan tertinggi adalah tujuan utama pemasaran (Kotler dan Amstrong, 2007).

Berdasarkan latar belakang tersebut peneliti ingin mengetahui dan menganalisis tentang sikap konsumen terhadap daging ayam pedaging di pasar tradisional serta berapakah tingkat kepuasan konsumen terhadap daging ayam pedaging di pasar tradisional. Studi tentang sikap dan kepuasan konsumen sangat diperlukan agar proses pemasaran berjalan lebih efektif dan efesien

\section{METODE PENELITIAN}

\section{A. Metode Pengumpulan Data}

Penelitian yang dilakukan adalah penelitian deskriptif. Data yang digunakan dalam penelitian ini berupa data primer dan sekunder. Data primer diperoleh melalui wawancara langsung dengan alat bantu kuisioner yang diajukan kepada konsumen akhir ayam pedaging. Data sekunder yang digunakan merupakan data penunjang penelitian yang diperoleh melalui instansiinstansi terkait seperti Badan Pusat Statistika, situs resmi departemen terkait dan dinas atau instansi pemerintahan setempat. Data tambahan diperoleh melalui buku-buku, internet, penelitian terdahulu dan literatur lainnya yang berkitan dengan penelitian.

\section{B. Metode Pengambilan Sampel}

Penentuan sampel responden dilakukan dengan menggunakan metode purpossive sampling. Cara pengambilan sampel dengan cara accidental sampling, yaitu responden yang kebetulan membeli daging ayam dan bersedia untuk diwawancara. Sampel yang diambil dalam penelitian ini sebanyak 50 responden.

Penentuan jumlah responden pada masingmasing pasar tradisional sampel ditentukan 
secara proporsional, karena jumlah pedagang daging ayam tidak sama besar di setiap pasar yang menjadi lokasi penelitian. Penentuan jumlah responden secara proporsional dapat dihitung dengan menggunakan rumus :

$$
N i=\frac{N k}{N} X 50
$$

Keterangan :

$\mathrm{Ni}$ : Jumlah responden tiap pasar
$\mathrm{Nk}$ : Jumlah pedagang daging ayam tiap pasar sampel

$\mathrm{N}$ : Total jumlah pedagang daging ayam pada pasar sampel

(Sugiyono, 2014)

Berdasarkan perhitungan tersebut maka dapat ditentukan jumlah responden pada setiap pasar sampel seperti yang dapat dilihat pada tabel berikut ini.

Tabel 1. Jumlah Responden di Setiap Pasar Sampel

\begin{tabular}{clcc}
\hline No & Nama Pasar & $\begin{array}{c}\text { Jumlah Pedagang Daging } \\
\text { Ayam } \\
\text { Pedaging (Orang) }\end{array}$ & Jumlah Responden (Orang) \\
\hline 1. & Pasar Baqa & 25 & 10 \\
2. & Pasar Segiri & 70 & 26 \\
3. & Pasar Pagi & 38 & 14 \\
\hline Total & & 133 & 50 \\
\hline
\end{tabular}

Sumber: Dinas Pengelola Pasar Kota Samarinda, 2016.

\section{Definisi Variabel dan Pengukurannya}

1. Responden merupakan pengambil keputusan dalam melakukan pembelian daging ayam ras yang mewakili rumah tangga dengan tujuan untuk dikonsumsi rumah tangga.

2. Karkas ayam pedaging adalah bahan makanan yang dikonsumsi manusia yang berasal dari ternak unggas yaitu ayam pedaging.

3. Atribut yaitu ciri-ciri atau karakteristik yang dimiliki oleh suatu produk yang berfungsi sebagai kriteria penilaian dalam pengambilan keputusan. Atribut yang akan diteliti meliputi: warna karkas ayam pedaging, kebersihan kulit karkas ayam pedaging, bau karkas ayam pedaging, bobot karkas ayam pedaging dan harga karkas ayam pedaging.

4. Warna karkas ayam pedaging, berkaitan dengan anggapan dan kesan konsumen terhadap warna daging ayam pedaging.

5. Kebersihan kulit karkas ayam pedaging, berkaitan dengan anggapan dan kesan konsumen terhadap kebersihan kulit ayam pedaging yang mengindikasikan baik tidaknya kualitas daging ayam pedaging.

6. Aroma karkas ayam pedaging, berkaitan dengan anggapan dan kesan konsumen terhadap bau daging ayam pedaging yang dapat mengindikasikan baik tidaknya kualitas daging ayam pedaging.

7. Bobot daging ayam pedaging, berkaitan dengan anggapan dan kesan konsumen tentang kepuasan yang didapat dari bobot atau berat daging ayam pedaging.

8. Harga karkas ayam pedaging, berkaitan dengan anggapan dan kesan karkas ayam pedaging oleh konsumen pada tingkat kesukaan responden berdasarkan harga yang telah ditetapkan.

9. Sikap yaitu evaluasi secara keseluruhan terhadap suatu produk yang akan dibeli untuk memuaskan kebutuhan yang dinyatakan dalam indeks sikap yang diukur dengan menjumlahkan perkalian antara kekuatan kepercayaan kinerja terhadap atribut dengan evaluasi kepentingan mengenai atribut-atribut tersebut.

10. Tingkat kepercayaan konsumen (bi) adalah kepercayaan konsumen terhadap kinerja atribut tertentu. Diukur dengan menggunakan skala Likert, yaitu 1 sangat tidak baik, 2 tidak baik, 3 netral, 4 baik, dan 5 sangat baik.

11. Evaluasi konsumen (ei) adalah evaluasi kepentingan konsumen terhadap atribut karkas ayam pedaging. Diukur dengan menggunakan skala Likert, yaitu 1 sangat 
tidak penting, 2 tidak penting, 3 netral, 4 penting, dan 5 sangat penting.

\section{Metode Analisis Data}

Metode analisis data yang digunakan dalam penelitian adalah analisis deskriptif dengan bantuan tabulasi deskriptif, metode Multiatribut Fishbein, dan analisis Customer Satisfaction Index. Pengolahan data menggunakan analysis software Microsoft Office Excel 2010.

\section{Analisis Deskriptif}

Analisis deskriptif adalah statistik yang digunakan untuk menganalisa data dengan cara menggambarkan atau mendeskripsikan data yang telah terkumpul sebagaimana adanya tanpa bermaksud untuk membuat kesimpulan yang berlaku untuk umum (Sugiyono, 2014). Analisis statistik deskriptif dapat digunakan bila hanya ingin mendeskripsikan sampel, dan tidak ingin membuat kesimpulan yang berlaku untuk populasi dimana sampel diambil.

\section{Skala Likert dan Rentang Skala \\ a. Skala Likert}

Skala Likert digunakan untuk mengukur tanggapan konsumen terhadap karakteristik dari suatu produk yang memungkinkan konsumen mengekspresikan intensitas perasaan mereka. Skala Likert beserta skor jawaban responden yang digunakan dalam penelitian ini dapat dilihat pada Tabel 2 .

Tabel 2. Skala Likert dan skor jawaban responden

\begin{tabular}{clc}
\hline No & Jawaban Responden & Skor \\
\hline 1. & Sangat tidak penting, Sangat tidak baik & 1 \\
2. & Tidak penting, Tidak baik & 2 \\
3. & Netral & 3 \\
4. & Penting, Baik & 4 \\
5. & Sangat penting, Sangat baik & 5 \\
\hline
\end{tabular}

(Sugiyono, 2014)

Tahapan penggunaan skala Likert adalah :

1. Peneliti mengumpulkan karakteristik yang relevan dengan permasalahan yang diteliti.

2. Semua karakteristik tersebut dimintakan tanggapan dari responden yang dimana jawaban konsumen telah disediakan dan terdapat pilihan jawaban.

3. Tanggapan tersebut dikumpulkan dan jawaban dikonversikan ke skala nilai yang terkait dengan bobot tanggapan. Tanggapan dengan indikasi menyenangi diberikan skor tertinggi atau sebaliknya. Skor lima untuk tanggapan tertinggi dan satu jawaban tanggapan terendah.

\section{b. Rentang Skala}

Berdasarkan jawaban responden akan diperoleh satu kecendrungan atas jawaban responden tersebut. Rentang skala dgunakan untuk perhitungan skor dan interprestasi terhadap penilaian konsumen . Berikut adalah rumus rentang skala

Rumus rentang skala :

$R S=\frac{(m-n)}{b}$

Keterangan:

$\mathrm{m}=$ angka tertinggi dalam pengukuran

$\mathrm{n}=$ angka terendah dalam pengukuran

$\mathrm{b}=$ banyaknya kelas yang terbentuk

(Simamora, 2004)

Besarnya range untuk evaluasi kepentingan dan tingkat kinerja (pelaksanaan) adalah : (5-1)/5 $=0,8$. Setelah range diketahui kemudian dilakukan pembagian kelas berdasarkan tingkat kepentingan : 


\begin{tabular}{cll}
\hline No & Range & \multicolumn{1}{c}{ Keterangan } \\
\hline 1. & $1,00-1,79$ & Sangat tidak penting \\
2. & $1,80-2,59$ & Tidak penting \\
3. & $2,60-3,39$ & Netral \\
4. & $3,40-4,19$ & Penting \\
5. & $4,20-5,00$ & Sangat penting \\
\hline
\end{tabular}

Sedangkan pembagian kelas berdasarkan tingkat kinerja adalah :

Tabel 4. Rentang skala tingkat kinerja

\begin{tabular}{cll}
\hline No & Range & \multicolumn{1}{c}{ Keterangan } \\
\hline 1. & $1,00-1,79$ & Sangat tidak baik \\
2. & $1,80-2,59$ & Tidak baik \\
3. & $2,60-3,39$ & Netral \\
4. & $3,40-4,19$ & Baik \\
5. & $4,20-5,00$ & Sangat baik \\
\hline
\end{tabular}

Selanjutnya nilai sikap (Ao) merupakan perkalian antara kepentingan dan kepercayaan kinerja atribut (Simamora, 2004). Besarnya range sikap adalah $[(5 \times 5)-(1 \times 1)] / 4=6$ pembagian kelas berdasarkan nilai sikap adalah:

Tabel 5. Rentang skala sikap setiap atribut

\begin{tabular}{cl}
\hline Range & Keterangan \\
\hline $1,00-6,99$ & Sangat Negatif \\
$7,00-12,99$ & Negatif \\
$13,00-18,99$ & Positif \\
$19,00-25,00$ & Sangat Positif \\
\hline
\end{tabular}

Sedangkan nilai sikap (Ao) total, nilai range diperoleh dari $[(25 \times 5)-(1 \times 5)] / 4=30$ sehingga diperoleh pembagian kelas sikap (Ao) total sebagai berikut:

Tabel 6. Rentang skala sikap total terhadap karkas ayam pedaging

\begin{tabular}{cl}
\hline Range & Keterangan \\
\hline $5,00-34,99$ & Sangat Negatif \\
$35,00-64,99$ & Negatif \\
$65,00-94,99$ & Positif \\
$95,00-125,00$ & Sangat Positif \\
\hline
\end{tabular}

\section{Model Sikap Multiatribut Fishbein}

Model sikap multiatribut Fishbein dapat digunakan untuk mengetahui hubungan antara pengetahuan produk yang dimiliki konsumen dengan sikap terhadap produk berkenaan dengan ciri atribut produk. Model multiatribut Fishbein mengidentifikasi bagaimana konsumen mengkombinasikan keyakinan mereka mengenai atribut-atribut produk sehingga akan membentuk sikap mereka terhadap berbagai merek alternatif. Apabila konsumen memiliki sikap yang mendukung terhadap suatu merek, maka produk tersebut akan dipilih dan dibelinya.

Rumus model Fishbein yang dimaksud adalah sebagai berikut :

$A_{o}=\sum_{i=1}^{n} b i . e i$

Dimana :

$A_{o}:$ Sikap konsumen terhadap objek 
bi : Tingkat keyakinan konsumen terhadap kinerja atribut tertentu (atribut ke-i)

ei : Dimensi evaluatif kepentingan konsumen terhadap variabel ke-i

(Prasetijo dan Ihalauw,2005)

Langkah-langkah dari pengukuran sikap konsumen dengan model Fishbein yaitu sebagai berikut:

a. Menentukan atribut produk daging ayam pedaging yang relevan

b. Membuat pertanyaan untuk mengevaluasi kepentingan (ei) atribut produk

c. Membuat pertanyaan untuk mengukur tingkat kepercayaan konsumen (bi) terhadap kinerja atribut produk

d. Langkah terakhir untuk menganalis data didapatkan dari mengalikan antara skor tingkat kepercayaan kinerja atribut (bi) dengan skor evaluasi kepentingan (ei) sehingga didapat nilai sikap (Ao), kemudian dijumlahkan untuk mengetahui sikap konsumen terhadap karkas ayam pedaging.

\section{Customers Satisfaction Index (CSI)}

Customers Satisfaction Index atau Indeks Kepuasan Pengguna (IKP) merupakan metode yang menggunakan indeks untuk mengukur tingkat kepuasan konsumen secara menyeluruh terhadap kinerja atribut-atribut ayam pedaging. Ada empat langkah dalam perhitungan IKP (Massnick, 1997 dalam Afifi, 2007), yaitu

a. Menentukan Means Important Score (MIS) dan Mean Satification Score (MSS). Nilai ini didapat dari nilai rata-rata tingkat kepentingan dan nilai rata-rata kinerja tiap responden.

$$
\begin{aligned}
M I S & =\left[\sum_{i=1}^{n} Y i\right] / n \\
M S S & =\left[\sum_{i=1}^{n} X i\right] / n
\end{aligned}
$$

Dimana :

$\mathrm{n}=$ Jumlah responden

$\mathrm{Yi}=$ nilai kepentingan atribut ke $\mathrm{i}$

$\mathrm{Xi}=$ nilai kinerja atribut ke $\mathrm{i}$

b. Membuat Weight Factors (WF), bobot ini merupakan persentase nilai MIS per-atribut terhadap total MIS seluruh atribut.

$W F=\frac{M I S i}{M I S t} \times 100 \%$
Dimana :

$\mathrm{P}=$ jumlah atribut kepentingan

$\mathrm{i}=$ Atribut ke i

c. Membuat Weight Score (WS), bobot ini merupakan perkalian antara Weight Factors (WF) dengan Mean Satification Score (MSS)

$W S i=W F i \times M S S i$

d. Menentukan nilai IKP

$I K P=\frac{\sum W S i}{H S} \times 100 \%$

Dimana :

$\mathrm{WSi}=$ hasil kali Weight Factors (WF) dengan Mean Satification Score (MSS)

$\mathrm{HS}=$ Skala maksimum yang digunakan

Kriteria indeks kepuasan menggunakan kisaran 0 hingga 100\% (tidak puas hingga sangat puas), yaitu kepuasan tertinggi dicapai bila CSI menunjukkan $100 \%$.

\section{HASIL DAN PEMBAHASAN}

\section{A. Karakteristik Responden}

Berdasarkan penelitian yang sudah dilakukan, diketahui bahwa 50 responden terbagi dalam 43 orang ( $86 \%$ ) perempuan dan 7 orang (14\%) laki-laki. Berdasarkan umur, diketahui bahwa usia paruh baya menduduki peringkat tertinggi $70 \%$ diikuti tua $18 \%$ dan dewasa lanjut sebesar $12 \%$. Tingkat pendidikan responden tertinggi yaitu SLTA 78\% dilanjutkan SLTP 14\% dan S1 sebesar 8\%. Jenis Pekerjaan responden dari yang paling tinggi sampai dengan yang paling rendah yaitu ibu rumah tangga, wiraswasta, swasta dan PNS berturut-turut nilainya sebesar $64 \%, 20 \%, 8 \%$ dan $8 \%$. Rata-rata pendapatan responden adalah Rp 2.000.000,- sampai dengan 2.999.000,- yaitu sebanyak 28 orang $(56 \%)$ responden. Alasan utama responden membeli di pasar tradisional adalah karena lokasi yang lebih dekat (40\%) disusul banyak pilihan $(32 \%)$ dan karena bias membeli keperluan lain (20\%). Frekuensi pembelian oleh responden paling tinggi yaitu 1 minggu sekali (sebanyak 92\% responden). Karakteristik karkas yang baik menurut responden adalah karkas dengan warna putih kekuningan, tidak berbau amis, dan bebas dari memar. Karakteristik tersebut dipilih oleh sebanyak $62 \%$ responden. 


\section{B. Analisis Multiatribut Fishbein}

Analisis sikap konsumen dengan menggunakan model sikap Multiatribut Fishbein terhadap karkas ayam pedaging merupakan suatu gambaran penilaian konsumen terkait dengan atribut-atribut yang melekat pada produk karkas ayam. Prinsip pada model ini adalah menghitung nilai Ao (Attitude toward the object), yaitu sikap seseorang terhadap sebuah objek, yang dikenali melalui atribut-atribut yang melekat tersebut.
Komponen evaluasi (ei) mengukur evaluasi konsumen terhadap atribut dari karkas ayam pedaging, sedangkan komponen bi mengukur keyakinan konsumen terhadap atribut produk karkas ayam pedaging.

\section{Penilaian Evaluasi Produk}

Atribut yang dinilai adalah warna, bobot, aroma, kebersihan kulit dan harga. Tabel 7 . menyajikan penilaian responden untuk atribut evaluasi (ei) terhadap atribut karkas ayam pedaging.

Tabel 7. Penilaian Evaluasi Atribut Karkas Ayam Pedaging

\begin{tabular}{lcc}
\hline Atribut Karkas & Nilai evaluasi (ei) & Interprestasi \\
\hline Warna & 4,18 & Penting \\
Bobot & 4,08 & Penting \\
Aroma & 3,94 & Penting \\
Kebersihan kulit & 3,68 & Penting \\
Harga & 4,02 & Penting \\
\hline
\end{tabular}

Sumber: Data primer diolah (2017)

Data pada Tabel 7 menunjukkan atribut warna $(4,18)$ merupakan hal yang penting bagi para konsumen dalam membentuk sikap. Posisi kedua dalam pembentukan sikap konsumen terhadap karkas ayam adalah atribut bobot karkas $(4,08)$.

Atribut ketiga dalam pembentukan sikap konsumen sebelum membeli karkas adalah harga (4,02). Atribut keempat adalah aroma $(3,94)$ karkas dan atribut kebersihan kulit karkas dianggap penting $(3,68)$ merupakan atribut kelima dalam pembentukan sikap konsumen.

Atribut yang dinilai adalah warna, bobot, aroma, kebersihan kulit dan harga. Berdasarkan hasil pada Tabel 7, menunjukkan atribut warna $(4,18)$ merupakan hal yang paling penting bagi para konsumen dalam membentuk sikap terhadap karkas ayam pedaging. Hal tersebut dikarenakan atribut ini dapat diamati secara langsung sehingga mudah bagi konsumen untuk mempertimbangkan keputusan pembelian dengan atribut ini. Sifat produk pangan yang paling menarik perhatian pada konsumen dan paling cepat pula memberikan kesan disukai atau tidak disukai adalah warna (Purwati, 2007). Konsumen menilai karkas ayam yang terbaik adalah karkas yang memiliki warna kulit putih cerah kekuningan dan warna daging merah kekuningan mengkilat, dikarenakan warna tersebut terlihat lebih segar dan sehat.

Atribut kedua yang penting adalah atribut bobot karkas $(4,08)$. Ukuran bobot karkas adalah besar atau kecilnya bobot yang dimilki karkas ayam pedaging. Atribut bobot karkas menjadi faktor yang diaggap penting bagi sebagian besar konsumen, hal tersebut dikarenakan tuntutan dari konsumen bahwa selain karkas memiliki warna yang segar, memiliki bobot yang sesuai dengan keinginan menjadi bahan pertimbangan konsumen agar pemenuhan konsumsi keluarga terhadap daging ayam dapat terpenuhi.

Atribut ketiga yang dipentingkan konsumen terhadap karkas ayam adalah harga $(4,02)$. Harga merupakan nilai tukar produk untuk manfaat yang diberikan produk itu sendiri. Karkas yang segar dan besar akan lebih menarik perhatian konsumen sehingga konsumen tertarik untuk membeli karkas tersebut dengan harga yang menurut konsumen wajar dan terjangkau. Atribut harga sering dipentingkan konsumen sebelum pembelian daging ayam dikarenakan harga yang selalu naik turun, tetapi bukan berarti atribut harga 
adalah atribut yang utama yang dilihat saat pembelian daging ayam pedaging (Arfiansyah 2015).

Atribut keempat yang dinilai penting oleh konsumen adalah aroma karkas. Aroma karkas mengindikasikan baik atau tidaknya kualitas daging tersebut, jika beraroma menyengat atau busuk berarti daging tersebut sudah tidak layak dikonsumsi. Apabila aroma daging ayam pedaging segar dapat diketahui bahwa daging tersebut masih baru, segar, sehat (Ningrum, 2011).

Atribut kebersihan kulit karkas merupakan atribut kelima dalam pembentukan sikap konsumen dan yang dipentingkan konsumen.
Konsumen beranggapan bahwa kulit karkas ayam yang bersih dari bulu tunas dan memar mengindikasikan bahwa karkas ayam mendapatkan perlakuan yang baik dan tepat pada saat pemotongan. Perlakuan yang tepat saat pemotongan akan membuat kebersihan kulit karkas ayam pedaging terjaga, tidak ada memar, goresan, sobekan maupuan bulu-bulu jarum (Ningrum, 2011).

\section{Penilaian Kinerja Atribut}

Penilaian kinerja atribut pada karkas ayam brioler yang dijual di pasar tradisional dapat dilihat pada Tabel 8 .

Tabel 8. Penilaian Kinerja Atribut Karkas Ayam Pedaging

\begin{tabular}{lcc}
\hline Atribut karkas & Nilai kinerja (bi) & Interprestasi \\
\hline Warna & 4,02 & Baik \\
Bobot & 4,04 & Baik \\
Aroma & 4,00 & Baik \\
Kebersihan kulit & 3,96 & Baik \\
Harga & 3,26 & Netral \\
\hline
\end{tabular}

Sumber: Data primer diolah (2017).

Berdasarkan Tabel 8 atribut yang memiliki kepercayaan dan kinerja paling baik menurut responden adalah atribut bobot karkas dengan nilai kepercayaan diberikan responden sebesar 4,04, disusul oleh atribut warna sebesar 4,02 dan aroma dengan nilai kepercayaan diberikan responden sebesar 4,00. Kebersihan kulit mendapatkan nilai kepercayaan dari responden sebesar 3,96, dan atribut harga mendapatkan nilai kinerja terkecil 3,26.

Tabel 8 menunjukkan, atribut bobot mendapat nilai kinerja 4,04 dinilai baik karena berada direntang 3,40 - 4,19. Responden percaya dan menyakini bahwa bobot karkas memiliki kenerja yang baik karena beragamnya karkas yang dipasarkan memiliki ukuran berbeda beda, sehingga konsumen bisa memilih karkas ayam sesuai dengan keinginan dan kebutuhan. Berdasarkan Standar Nasional Indonesia (2009), bobot karkas ayam terbagi menjadi 3 ukuran yakni ukuran kecil yang berbobot $<1,0 \mathrm{~kg}$, ukuran sedang $1,0 \mathrm{~kg}$ sampai dengan $1,3 \mathrm{~kg}$ dan ukuran besar dengan bobot $>1,3 \mathrm{~kg}$.

Atribut warna mendapat nilai kinerja 4,02 dinilai baik karena berada direntang 3,40 - 4,19.
Konsumen mengaggap bahwa karkas ayam yang di pasarkan memiliki warna yang mencerminkan karkas tersebut berkualitas baik, yakni memiliki warna kulit putih cerah kekuningan. Menurut Ismanto, et al. (2010), warna karkas yang akan dipasarkan harus mempunyai warna yang terang dan terlihat cerah, agar diminati oleh konsumen.

Aroma karkas merupakan salah satu indikator untuk menentukan karkas dalam kualitas yang bagus. Aroma mendapat nilai kinerja sebesar 4,00 dinilai baik karena berada direntang 3,40 - 4,19. Konsumen meyakini bahwa aroma karkas ayam pedaging baik karena yakin bahwa penjual akan menjual karkas berkualitas bagus untuk mendapatkan konsumen yang lebih banyak. Menurut Ningrum (2011), aroma karkas ayam dapat mengindikasikan baik atau tidaknya kualitas karkas ayam.

Kebersihan kulit mendapatkan nilai kepercayaan dari responden sebesar 3,96 dinilai baik karena berada direntang 3,40 - 4,19. Kebersihan kulit mendapat nilai kepercayaan kinerja yang dinilai baik dikarenakan kualitas kebersihan kulit karkas termasuk dalam 
kualitas yang bagus. Berdasarkan Standarisasi Nasional terhadap ayam pedaging bahwa tingkatan mutu fisik karkas, tentang kebersihan kulit terbagi menjadi tiga mutu yaitu pertama bebas dari bulu tunas, kedua ada bulu tunas sedikit yang menyebar tetapi tidak pada bagian dada dan yang ketiga adalah adanya bulu tunas (SNI 3924:2009).

Atribut harga mendapatkan nilai kinerja sebesar 3,26 yang dinilai netral karena berada direntang 2,60 - 3,39. Menunjukkan bahwa harga karkas ayam terbilang cukup mahal, dikarenakan waktu penelitian dilakukan menjelang hari besar keagamaan dan tahun baru, harga karkas ayam pedaging mengalami kenaikkan dari hari biasanya. Kenaikan harga yang cukup tinggi dikarenakan bertepatan dengan hari-hari besar ( hari raya keagamaan) yaitu sebesar Rp. 40.000,- hingga Rp 45.000,per ekor daging ayam potong (Dinas Peternakan Provinsi Kalimantan Timur, 2016).

\section{Indeks Sikap Konsumen}

Indeks sikap konsumen (Ao) didapatkan dengan mengalikan angka penilaian kepercayaan (bi) dan nilai evaluasi (ei) terhadap atribut karkas. Angka ini menunjukkan penilaian konsumen terhadap atribut yang melekat pada daging ayam pedaging yang meliputi warna, bobot, aroma, kebersihan kulit dan harga karkas. Adapun nilai dari indeks sikap konsumen (Ao) terhadap karkas ayam pedaging dapat dilihat pada Tabel 9 .

Tabel 9. Indeks Sikap Konsumen trhadap Atribut Ayam Pedaging

\begin{tabular}{lccccc}
\hline \multirow{2}{*}{ Atribut } & Bi & ei & \multicolumn{2}{c}{ Sikap (Ao) = bi.ei } & \multirow{2}{*}{ Peringkat } \\
\cline { 4 - 5 } & & 4,18 & 16,80 & Positif & I \\
Warna & 4,02 & 4,08 & 16,48 & Positif & II \\
Bobot & 4,04 & 3,94 & 15,76 & Positif & III \\
Aroma & 4,00 & 3,68 & 14,57 & Positif & IV \\
Kebersihan & 3,96 & 4,02 & 13,11 & Positif & V \\
kulit & 3,26 & & 76.07 & Positif & \\
Harga & & & &
\end{tabular}

Sumber: Data primer diolah (2017).

Berdasarkan Tabel 9 terlihat sikap konsumen terhadap karkas ayam pedaging di pasar tradisional Kota Samarinda adalah positif. Sikap konsumen terhadap atribut warna karkas adalah sikap yang paling tinggi sebesar 16,80 , diikuti oleh atribut bobot $(16,48)$, aroma $(15,76)$, kebersihan kulit $(14,57)$ dan harga $(13,11)$. Sementara sikap konsumen secara keseluhan terhadap karkas ayam pedaging adalah 76,07 atau bisa diartikan sebagai sikap positif.

Sikap konsumen terhadap atribut warna karkas adalah sikap yang paling tinggi sebesar 16,80 dan menjadi pertimbangan pertama konsumen sebelum membeli karkas ayam. Warna karkas berkaitan dengan kesegaran karkas ayam, sehingga konsumen menganggap atribut ini sangat di pertimbangkan sebelum membeli karkas ayam pedaging. Konsumen merasa atribut kesegaran daging ayam pedaging adalah hal yang utama dalam membentuk sikap terhadap objek dan pertimbangan utama, sebab kesegaran pada daging ayam akan memberikan dampak atau manfaat bagi diri konsumen (Arfiansyah 2015).

Atribut bobot $(16,48)$ yang dinilai positif karena berada direntang 13,00 - 18,99 dan merupakan atribut yang kedua dipertimbangkan konsumen. Atribut bobot karkas dipertimbangkan yang kedua karena tuntutan dari konsumen bahwa selain karkas memiliki warna yang segar, memiliki bobot yang sesuai dengan keinginan konsumen agar pemenuhan konsumsi keluarga terhadap daging ayam dapat terpenuhi. Konsumen memilih bobot daging ayam disesuaikan dengan pemenuhan kebutuhan konsumsi keluarga. Jika kebutuhan konsumsi keluarga untuk daging ayam ras banyak, maka bobot daging ayam ras yang dipilih adalah yang besar dan sebaliknya 
bila kebutuhan keluarga hanya sedikit maka dipilih bobot daging ayam ras yang sedang (Ningrum, 2011).

Aroma $(15,76)$ yang dinilai positif karena berada direntang 13,00 - 18,99. dan merupakan atribut yang ketiga dipertimbangkan konsumen. Konsumen memilih atribut aroma daging ayam pedaging sebagai atribut yang dipertimbangkan ketiga karena untuk menentukan karkas yang segar baik, konsumen hanya menentukan berdasarkan warna karkas yang sesuai dengan keinginan konsumen, yakni kulit berwarna putih cerah kekuningan dan daging berwarna merah kekuningan mengkilat. Menurut Soeparno (2005) faktor kualitas daging yang dimakan terutama adalah warna, keempukan dan tekstur, flavor dan aroma termasuk bau dan cita rasa serta kekhas-an jus daging (juiciness).

Kebersihan kulit mendapat nilai sikap sebesar 14,57 yang dinilai positif karena berada direntang 13,00 - 18,99 dan merupakan atribut yang keempat dipertimbangkan konsumen. Atribut kebersihan kulit kurang di pentingkan responden sehingga mendapatkan nilai sikap yang lebih rendah daripada atribut warna, bobot dan aroma. Sejalan dengan penelitian Ningrum (2011), bahwa kebersihan kulit karkas ayam menjadi atribut yang kurang dipertimbangkan karena konsumen masih dapat membersihkannya lagi, terutama untuk kulit yang masih banyak bulu-bulu jarumnya.

Harga mendapatkan nilai sikap 13,11 yang dinilai positif karena berada direntang 13,00 18,99 dan merupakan atribut yang kelima dipertimbangkan konsumen. Harga mendapatkan nilai sikap paling rendah daripada atribut warna, bobot, aroma dan kebersihan kulit, hal ini disebabkan oleh harga karkas yang cukup mahal saat menjelang hari-hari besar dan tahun baru.

Konsumen menganggap bahwa atribut warna dan aroma karkas berkualitas baik sehingga karkas ayam yang dibeli layak untuk dikonsumsi dan bobot karkas yang beragam membuat konsumen bisa memilih bobot karkas sesuai kebutuhan. Sementara sikap konsumen secara keseluhan terhadap karkas ayam pedaging adalah 76,07 atau bisa diartikan sebagai sikap positif yang dapat menerima dengan baik karkas ayam pedaging yang di pasar tradisional Kota Samarinda.

\section{Indek Kepuasan Pengguna (IKP)}

IKP digunakan untuk menganalisis tingkat kepuasan total konsumen dengan memperhitungkan nilai rata-rata tingkat kepentingan dan kinerja atribut karkas ayam pedaging. Nilai IKP karkas ayam pedaging dapat dilihat pada Tabel 10.

Tabel 10. Indeks kepuasan pengguna (IKP)

\begin{tabular}{llcccc}
\hline No & Atribut & $\begin{array}{c}\text { Mean } \\
\text { Important } \\
\text { Score (MIS) }\end{array}$ & $\begin{array}{c}\text { Mean } \\
\text { Statisfaction } \\
\text { Score (MSS) }\end{array}$ & $\begin{array}{c}\text { Weighting } \\
\text { Factors (WF) }\end{array}$ & $\begin{array}{c}\text { Weight } \\
\text { Score (WS) }\end{array}$ \\
\hline 1. & Warna & 4,18 & 4,02 & 0,21 & 0,84 \\
2. & Bobot & 4,08 & 4,04 & 0,21 & 0,83 \\
3. & Aroma & 3,94 & 4,00 & 0,20 & 0,79 \\
4. & Kebersihan kulit & 3,68 & 3,96 & 0,19 & 0,73 \\
5. & Harga & 4,02 & 3,26 & 0,20 & 0,66 \\
\hline Total & 19,90 & & & 3,86 \\
IKP & & & & $77,11 \%$ \\
\hline
\end{tabular}

Sumber: Data primer diolah (2017). 
Berdasarkan Tabel 22 nilai indeks kepuasan konsumen karkas ayam, dapat diketahui bahwa nilai IKP dari penelitian ini adalah sebesar $77,11 \%$. Hal ini menunjukkan bahwa kepuasan responden secara keseluruhan adalah puas karena berada pada rentang skala 60-80\% dan karkas ayam pedaging di pasar tradisional dinilai berkualitas cukup baik oleh konsumen terutama pada atribut aroma dan kebersihan kulit karkas mendapatkan nilai kinerja lebih tinggi dari kepentingan, sehingga konsumen merasa puas.

Atribut warna dan bobot karkas mendapatkan nilai kinerja yang mendekati nilai kepentingan sedangkan atribut harga mendapat nilai kinerja dibawah nilai kepentingan. Ketika kinerja sesuai dengan harapan atau kepentingan maka konsumen akan merasa puas, dan ketika kinerja melebihi harapan maka konsumen akan merasa sangat puas. Apabila kinerja dibawah harapan maka konsumen akan kecewa dan tidak puas (Supranto, 2006).

\section{KESIMPULAN}

1. Sikap konsumen terhadap karkas ayam pedaging adalah positif yang berarti kosumen menerima dengan baik karkas ayam pedaging di pasar tradisional kota Samarinda.

2. Berdasarkan analisis multiatribut Fishbein, atribut karkas ayam pedaging yang paling dipertimbangkan konsumen dalam keputusan pembelian karkas ayam pedaging di pasar tradisional Kota Samarinda secara berurutan adalah warna karkas, bobot karkas, aroma, kebersihan kulit dan harga karkas ayam pedaging.

3. Hasil analisis kepuasan berdasarkan IKP, diketahui bahwa tingkat kepuasan konsumen terhadap karkas ayam pedaging di pasar tradisional Kota Samarinda sebesar 77,11 persen yang berada pada kategori puas.

\section{DAFTAR PUSTAKA}

Afifi, MF. 2007. Analisis Kepuasan Konsumen Terhadap Atribut Sayuran Organik Dan Penerapan Personel Selling Benny's Organik Garden. Manajemen Agribisnis.
Fakultas Pertanian. Institut Pertanian Bogor. Bogor.

Arfiansyah, C. 2015. Analisis Sikap Konsumen Terhadap Nilai Atribut Daging Ayam Pedaging Di Kecamatan Sumbersari Kabupaten Jember. Manajemen Bisnis Unggas. Fakultas Peternakan. Politeknik Negeri Jember. Jember.

Badan Pusat Statistik. 2016. Kalimantan Timur dalam Angka. BPS Kota Samarinda, Kalimantan Timur. Samarinda.

Badan Standarisasi Nasional. 2006. Standar Nasional Indonesia (SNI). SNI 3924:2009. Mutu Karkas dan Daging Ayam. Dewan Standarisasi Indonesia. Jakarta.

Dinas Peternakan Provinsi Kalimantan Timur. 2016. Informasi Harga Pasar Komoditas Peternakan. Samarinda.

Ismanto, A., Masni dan Bilqies. 2010. Pengaruh Penambahan Kunyit (Curcuma domestica val) Atau Temulawak (Curcuma xanthorrhiza roxb) Dalam Air Minum Terhadap Persentase Dan Kualitas Organoleptik Karkas Ayam Pedaging. Jurnal Teknologi Pertanian 6(1):7-14

Kotler, P dan Amstrong, G. 2007. Prinsip Prinsip Pemasaran. Penerbit Erlangga. Jakarta.

Ningrum, S.S. 2011. Analisis Preferensi Konsumen Dalam Membeli Daging Ayam Ras Di Pasar Trasisional Kabupaten Karanganyar. Sosial Ekonomi Pertanian/Agrobisnis. Fakultas Pertanian Universitas Sebelas Maret Surakarta. Surakarta.

Prasetijo, R. dan John Ihalauw. 2005. Perilaku Konsumen. Penerbit Andi. Yogyakarta.

Pratama, E. 2013. Perilaku Pembelian Ayam Potong Broiler Di "Pasar keputran" Surabaya. (Skripsi). Fakultas Pertanian Universitas Pembangunan Nasional "Veteran". Jawa Timur.

Republik Indonesia. Undang Undang No. 18 Tahun 2009 Tentang Peternakan Dan Kesehatan Hewan. Jakarta.

Simamora, B., 2004, Riset Pemasaran. Gramedia Utama. Jakarta.

Soeparno, 2005. Ilmu dan Teknologi Daging.Cet. Ke-4. Gajah Mada University Press. Yogyakarta.

Sugiyono. 2014. Metode Penelitian Kuantitatif dan Kualitatif. CV Alfabeta. Bandung. 
Sumarwan, Ujang. 2004. Perilaku Konsumen : Teori dan Penerapannya dalam Pemasaran. Ghalia Indonesia dan MMA IPB. Jakarta.
Tambunan, R. D. 2009. Keempukan Daging dan Faktor-Faktor Yang Mempengaruhinya. Balai Pengkajian Teknologi Pertanian Lampung. Lampung. 